\title{
Article
}

\section{Reclaimed Mine Sites: Forests and Plant Diversity}

\author{
Pavla Vachova ${ }^{1, *(D)}$, Marek Vach ${ }^{2}$, Milan Skalicky ${ }^{1}\left(\mathbb{D}\right.$, Alena Walmsley $^{3}$, Martin Berka $^{3}$, Kamil Kraus $^{1}$, \\ Helena Hnilickova ${ }^{1}$ (D), Olga Vinduskova ${ }^{4}$ and Ondrej Mudrak ${ }^{5}$
}

1 Department of Botany and Plant Physiology, Faculty of Agrobiology, Food and Natural Resources, Czech University of Life Sciences Prague, 16500 Prague, Czech Republic; skalicky@af.czu.cz (M.S.); krausk@af.czu.cz (K.K.); hnilickova@af.czu.cz (H.H.)

2 Department of Water Resources and Environmental Modeling, Faculty of Environmental Sciences, Czech University of Life Sciences Prague, 16500 Prague, Czech Republic; vachm@fzp.czu.cz

3 Department of Land Use and Improvement, Faculty of Environmental Sciences, Czech University of Life Sciences Prague, 16500 Praha, Czech Republic; walmsley@fzp.czu.cz (A.W.); mberka@fzp.czu.cz (M.B.)

4 Institute for Environmental Studies, Faculty of Science, Charles University, 12801 Prague, Czech Republic; olga.vinduskova@gmail.com

5 Department of Functional Ecology, Institute of Botany, The Czech Academy of Sciences, 37982 Trebon, Czech Republic; ondrej.mudrak@ibot.cas.cz

* Correspondence: vachovap@af.czu.cz; Tel.: +420-22438-2516

check for updates

Citation: Vachova, P.; Vach, M. Skalicky, M.; Walmsley, A.; Berka, M.; Kraus, K.; Hnilickova, H.;

Vinduskova, O.; Mudrak, O.

Reclaimed Mine Sites: Forests and Plant Diversity. Diversity 2022, 14, 13. https://doi.org/10.3390/d14010013

Academic Editor: Michael Wink

Received: 10 December 2021

Accepted: 24 December 2021

Published: 28 December 2021

Publisher's Note: MDPI stays neutral with regard to jurisdictional claims in published maps and institutional affiliations.

Copyright: (C) 2021 by the authors. Licensee MDPI, Basel, Switzerland. This article is an open access article distributed under the terms and conditions of the Creative Commons Attribution (CC BY) license (https:// creativecommons.org/licenses/by/ $4.0 /)$.

\begin{abstract}
The relationship between vegetation and selected soil characteristics in different monoculture forest types was investigated as part of a landscape restoration project after brown coal mining. Six forest types were selected: alder (Alnus sp.), spruce (Picea sp.), pine (Pinus sp.), larch (Larix sp.), long-term deciduous forest (Quercus robur, Tilia sp.), and forest created by spontaneous succession. These stands were classified into two age categories (younger and older). The soil attributes, C/N, TC, $\mathrm{TN}, \mathrm{pH}$, and A horizon depth were assessed. The observed species were categorized into functional groups by life history, life forms according to Raunkiær, and affinity to the forest environment. C/N ratio, humus thickness, and canopy cover were the main soil parameters affecting plant communities. The highest $\mathrm{C} / \mathrm{N}$ values were recorded in Pinus and Larix stands, which were significantly different from deciduous and succession stands. The highest diversity index was noted in younger stands of Alnus and the lowest in younger stands of Picea. Intermediate values of the diversity index were achieved in successional stands at both age levels and in Larix and Alnus stands. The species belonging to a functional group was not an important factor in these habitat types. The species composition and vegetation change over time in the Alnus, long-life deciduous, and Larix stands show that these species are more suitable for forestry reclamation than spruce or pine. The study also emphasizes the great value of spontaneous succession areas as full-fledged alternatives to forestry reclamation.
\end{abstract}

Keywords: forestry reclamation; spontaneous succession; plant diversity; spoil heaps; $\mathrm{C} / \mathrm{N}$

\section{Introduction}

Localities affected by coal mining have a specifically configured landscape with soil always playing a very important role. By dumping mine waste, new habitats with great biological potential are created [1,2]. Soil affects dominance, vegetation dynamics, and succession [3-5], but most landfill areas have been technically renewed. Forestry reclamation has involved mainly monoculture stands, but for technical reclamation, non-native trees and shrubs are sometimes used [6,7], which can be unsuitable because of their invasive potential [8,9]. If the source of diaspores of an invasive species is located close to a successional area, these areas are susceptible to invasion [10]. Due to their often allelopathic characteristics and influence on soil chemistry, these species can negatively impact biodiversity.

It is highly advisable that new mining sites are colonized by native species that will naturally fill the ecological niche and, thus, contribute to better landscape stability. However, as nutrient availability increases, spoil heaps can become targets for invasive species 
because of their excess resources. If habitat conditions change rapidly, for example, by the addition of nitrogen [11], the new conditions may favour the expansion of undesirable species, which then prosper at the expense of diversity [12]. The availability of nutrients that are important to a species can affect the dispersion of that species in the environment [13]. The community's response to the supplied nutrients tends to be very rapid and usually leads to a reduction in species richness at the local level [14]. Nitrogen, phosphorus, and potassium (the NPK nutrients) can quickly change the species composition in an area [15]. This can be particularly problematic in alder (Alnus) stands, where natural nitrogen fixation occurs, and undesirable species such as Calamagrostis epigejos or Arrhenatherum elatius can spread [16-18]. There is probably no such danger in spontaneous succession because the community naturally tends towards stability in which community members use resources efficiently and sustainably $[19,20]$.

The 'Velká Podkrušnohorská' spoil heap (Czechia) consists of both forestry reclamation and spontaneous succession. Vegetation on technical reclamation develops differently from that under spontaneous succession [21]. On flat areas left to spontaneous succession, grasslands with Calamagrostis epigejos dominance develop [18,22-24]. If the area is not aligned (waves are left from the conveyor belt), it can develop into a forest stand [22,25]. It is very difficult to classify plant communities formed on sites affected by anthropogenic activities into a syntaxon. The vegetation on an anthropogenic site is described as a complex resulting from successional stages [26]. New communities develop on substrates that are quite different in physical, chemical, and biological properties from the original ones. This happens despite the altered geomorphology, which takes a long time to form in the natural environment.

Forestry reclamations have so far always been implemented as monoculture patches that closely follow each other. However, these specific stands should be planted as a mosaic of diverse habitats with a technical and successional component $[27,28]$. The chosen dominant tree species strongly influences pedogenesis, the water requirement, and the herbaceous community [18,29-32]. The vegetation, soil, and soil biota are components that are closely intertwined and interdependent [33] and are very much influenced by the composition of tree species, which strongly affect the biological properties of soils [34]. Vegetation composition is also influenced by the distance from source areas [35].

The main aim of our work was to determine which tree type for forest monoculture was the most suitable alternative for succession. It is already known that spontaneously restored areas have higher plant diversity than technically reclaimed sites [21]; however, there is still a legal obligation to restore an area to the habitat type present before mining [36]. It is, therefore, not desirable or even possible to leave all areas to spontaneous succession. We, therefore, defined three sub-objectives: (1) to find and define differences in herbaceous vegetation between different types of forestry reclamation represented by the type of dominant tree species in the tree canopy (Picea abies, Pinus sp., Larix decidua, long lived deciduous, and Alnus sp., and spontaneous succession) in relation to soil properties; (2) to determine, from the measured soil properties, the parameter that best reflects the variability in specific vegetation of the spoil heaps and which factor is key to the formation of the herbaceous vegetation; and (3) to compare the diversity, species abundance, life history, life form, and affinity to the forest environment of selected forest reclamation stands with spontaneous succession in two age categories.

\section{Materials and Methods}

\subsection{Site Characteristics}

The study was conducted on the 'Velká Podkrušnohorská' spoil heaps in Czechia $\left(50^{\circ} 14^{\prime} 31^{\prime \prime} \mathrm{N}, 12^{\circ} 40^{\prime} 45^{\prime \prime} \mathrm{E}\right)$ (Figure 1). This site contains mainly tertiary clays of the Cypris series, which are composed mainly of montmorillonite, illite, and caolinite and are well supplied with mineral nutrients (total $\mathrm{P}$, especially). This is the overburden material from a nearby lignite mine [37]. The mean annual precipitation is $800 \mathrm{~mm}$, and the mean annual temperature is $7^{\circ} \mathrm{C}[38]$. The $\mathrm{pH}$ of the substrate in the initial successional stages was 8 to 9 [39]. 


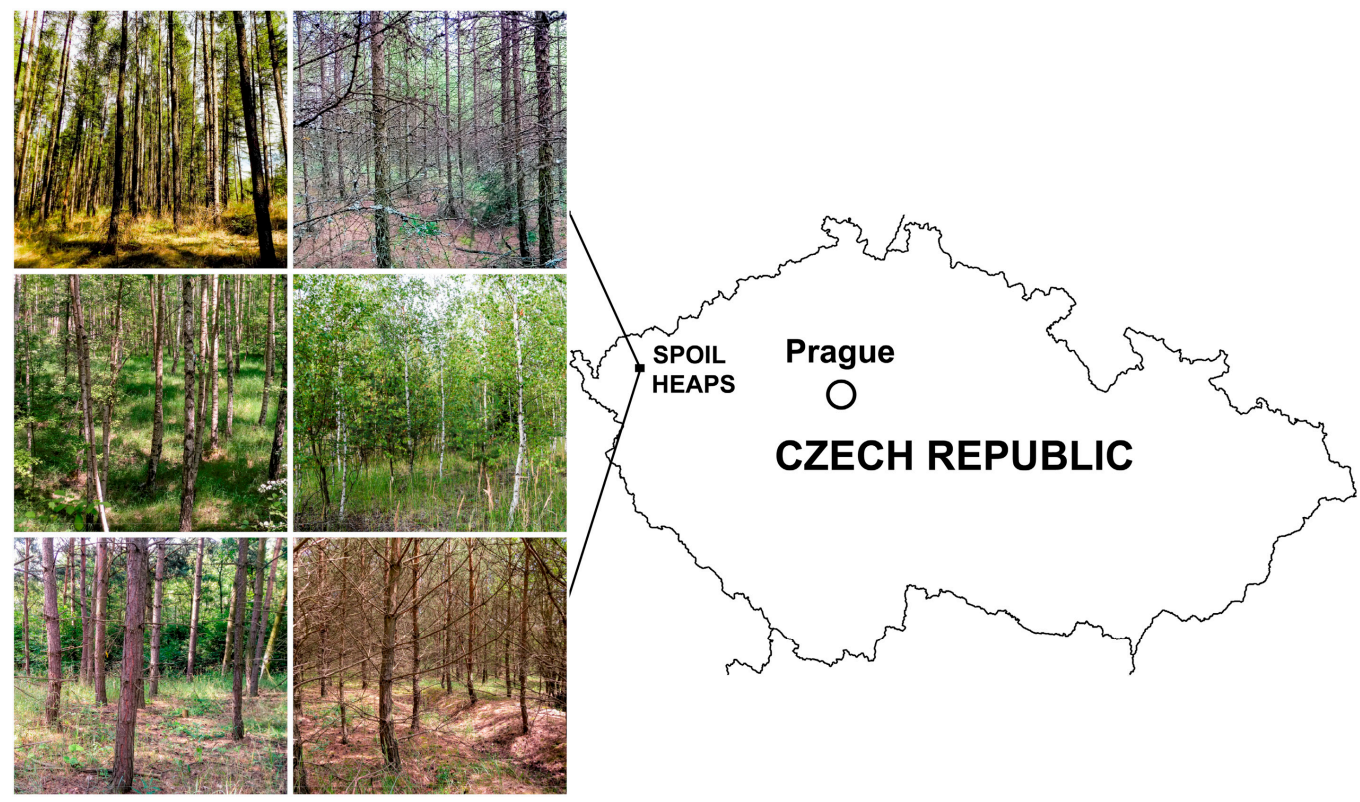

Figure 1. Location of the studied spoil heaps.

Technical reclamation was carried out by direct planting of selected seedlings, and the total area of the experimental planting was $\sim 2000$ ha. The gradual re-cultivation has created a mosaic of forest stands of different ages. In the study site, there are mainly stands of pine (Pinus sp.) and spruce (Picea sp.), alder (Alnus sp.) and larch (Larix decidua), summer oak (Quercus robur), and lime (Tilia sp.). Smaller areas were left to spontaneous succession. Six types of forest stands in two age categories were selected for the vegetation study. Five habitat types were created by forestry reclamation as monoculture forests consisting of (1) Norway spruce (Picea abies), (2) pine (Pinus sp.), (3) larch (Larix decidua), (4) long-aged deciduous trees-small-leaved lime, English oak (Tilia cordata, Quercus robur), and (5) alder (Alnus sp.). One forest type included in the study was formed by spontaneous succession (6) as a combination of willow (Salix) and birch (Betula). For this study, stands of two age categories were selected. The older forest is approximately $30-40$ years old, and the younger forest is approximately 20 years old.

\subsection{Study Design and Data Sampling}

Vegetation composition was studied in 36 plots (six forest types, two age categories, three replicates). The size of the plots was set according to similar studies as a $5 \times 5 \mathrm{~m}$ square placed in the centre of the study plot represented by forest type and age [18]. Data collection took place during the growing season (July and August). In each plot, the herbaceous, shrub, and tree species (canopy cover) found were recorded, and their percent cover was estimated. Communities occurring under these conditions were described by dividing them into functional groups (if such a formation existed for the species). These groups characterize individual species from different aspects: (1) life histories-according to population strategies, i.e., response to external stimuli; we used the classical Grimm division into C/S/R (competitive/stress/ruderal) strategies and their combinations; (2) life forms according to Raunkiær-according to the deposition of regenerating buds, respectively. We divide them into nanophanerophyte (NF), hemicryptophyte (HF), geophyte $(\mathrm{G})$, therophyte (T), and macrophanerophyte (MF); or (3) affinity to the forest environment (i.e., whether the species occurs in the forest or not) [40]. Simpson's diversity index (D) was calculated for each plot. Soil samples were taken by sampler lawns from the top of the mineral soil (after removal of the litter and organic horizon with trace of fermentation processes) at five randomly selected points within each square simultaneously with the species inventory. The sampler has a diameter of $23 \mathrm{~mm}$ and a length of $10 \mathrm{~cm}$. Samples were dried at room temperature and sieved through fine-sieve with a mesh size of $2 \mathrm{~mm}$. Total soil carbon (C) 
and total soil nitrogen $(\mathrm{N})$ were determined from these samples using a Primacs SNC-100 $\mathrm{CN}$ analyser. In addition, the depth of horizon A (humus) and pH were measured. The soil $\mathrm{pH}$ values were determined after extraction with $0.01 \mathrm{M} \mathrm{CaCl}_{2}$ at a ratio of $1: 2.5(\mathrm{w} / \mathrm{v})$.

\subsection{Data Analysis}

Factorial ANOVA was used to compare variables measured in the field and in the laboratory. After significant results were obtained $(p<0.05)$, multiple comparisons using Tukey's HSD test were used to identify significant differences between treatments. All analyses were performed using Statistica ver13.5 software (Statsoft, Tulsa, OK, USA). Canonical correspondence analysis (CCA) was used to visualize differences in plant community composition in the context of the variables of interest. Forest type and age were used as additional categorical variables. The variables (from C/N, TN, TC, pH, A horizon depth, and canopy) that best captured the variability in our data were tested and selected using the forward selection function, and a Bonferroni correction was applied to reduce the probability of first-order error [41]. Canoco 5 software was used for CCA with additional variables, variability distributions, and other projections [42].

\section{Results}

The newly formed substrates were first colonized by R-strategy plants, which are annuals-therophytes that tolerate frequent disturbances, quickly colonize open areas, and reproduce rapidly. Species with this strategy leave alder stands, long-lived deciduous trees, spruce (Picea), and pine (Pinus) in the younger growth stages. During habitat development, R-strategists are replaced by competitively stronger C-strategists or species that carry this strategy at least in combination (Figure 2). However, C-strategists do not tolerate stress and disturbance. The highest proportion of competitive strategists relative to the average number of species was recorded in Larix stands. S-strategists, which tolerate stress well, were not seen in the experimental plots. This category is present only as mixed CS-strategists in all stands except stands in the younger growth stage of succession and Picea stands in both categories. Species with the SR strategy occurred only in the younger growth phase of longleaf deciduous stands and in the growth phase of successional stands of willow and birch. Of the intermediate phases, species with a CSR strategy were the most abundant in all categories surveyed, which is not uncommon on sites such as these.

The distribution of plants into Raunkiær life forms was fairly even across all vegetation types (Figure 3). Only in successional stands was the proportion of hemicryptophytes the highest, while geophytes, therophytes, and macrophanerophytes were less represented than in the other forest types studied. The presence of macrophanerophytes in the herbaceous layer indicates natural rejuvenation of the stands. The number of species relative to total herb abundance is visualized in Figure 4. The highest abundances were found in stands of Alnus at the younger and older stages, but in neither case were stands with the highest number of species detected. Most species were collected in stands of Larix and long-statured broadleaves, where there was also a relatively good involvement of the herbal layer (abundance). The lowest abundance was recorded in Picea stands at both ages. The successional stands were in the middle values of the measured data. This is a balanced relationship between abundance and number of species. A similar equilibrium was recorded in older stands of Pinus and long-aged broadleaves. Some stability in successional stands is shown in Figure 5. In the younger successional stages, non-forest or rather non-forest species (species occurring partly in forest but mainly in open vegetation) dominate with a smaller proportion of inert and forest species. During succession, the species that prefer treeless conditions recede and inert or forest species predominate, while the proportion of species that do not grow spontaneously in forests decreases. Regardless of stand type, the proportion of species in both forest and non-forest vegetation increases with age. This change was least evident in the Picea stand, where, however, there were no forest-associated species in either age group. The species found here are generally found outside of forest habitats or are more likely to be non-forest species. 


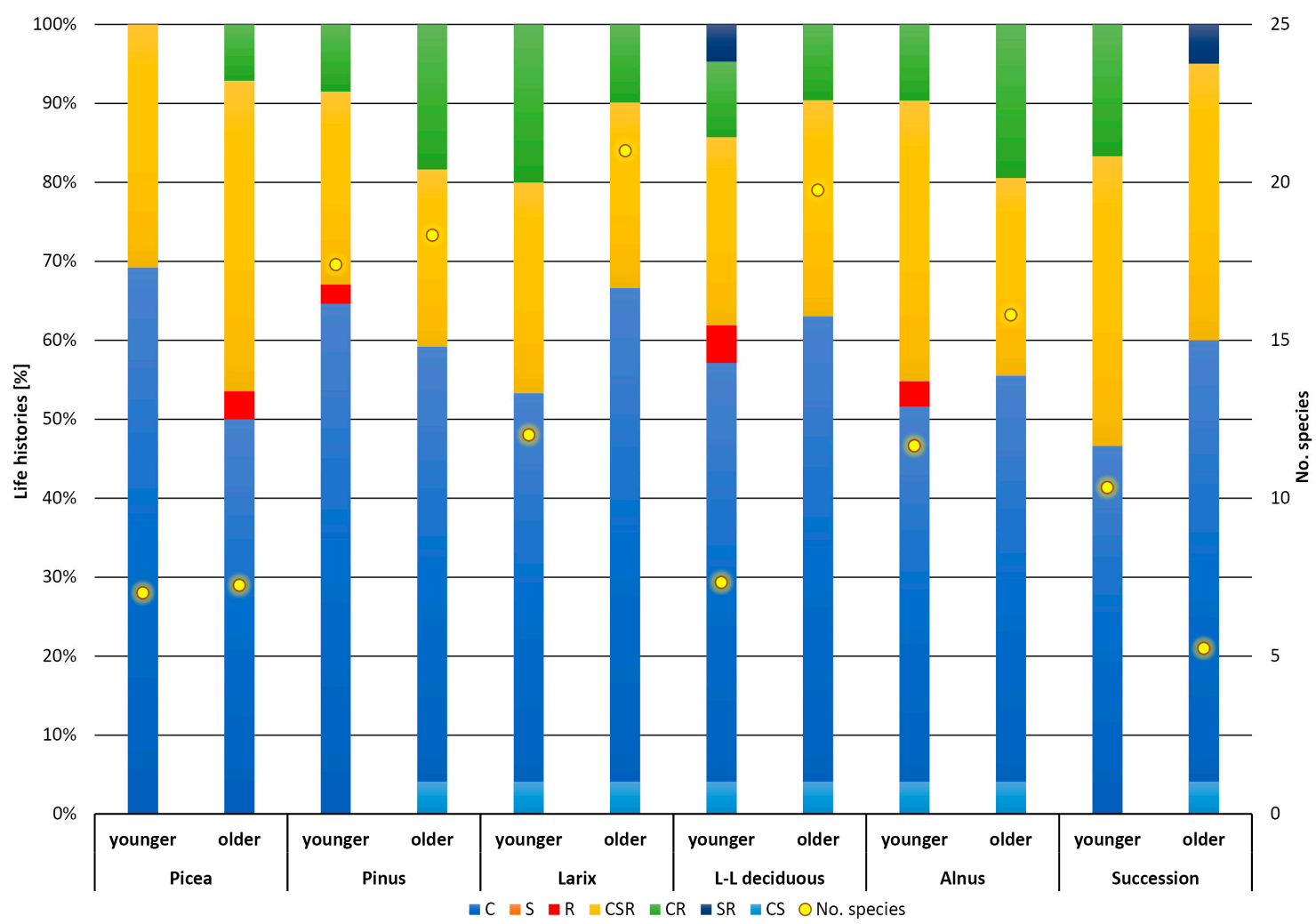

Figure 2. Life histories-distribution of functional groups in forest type and different ages. C-competitors, S-stress strategy, R-ruderal strategy, and their combinations.

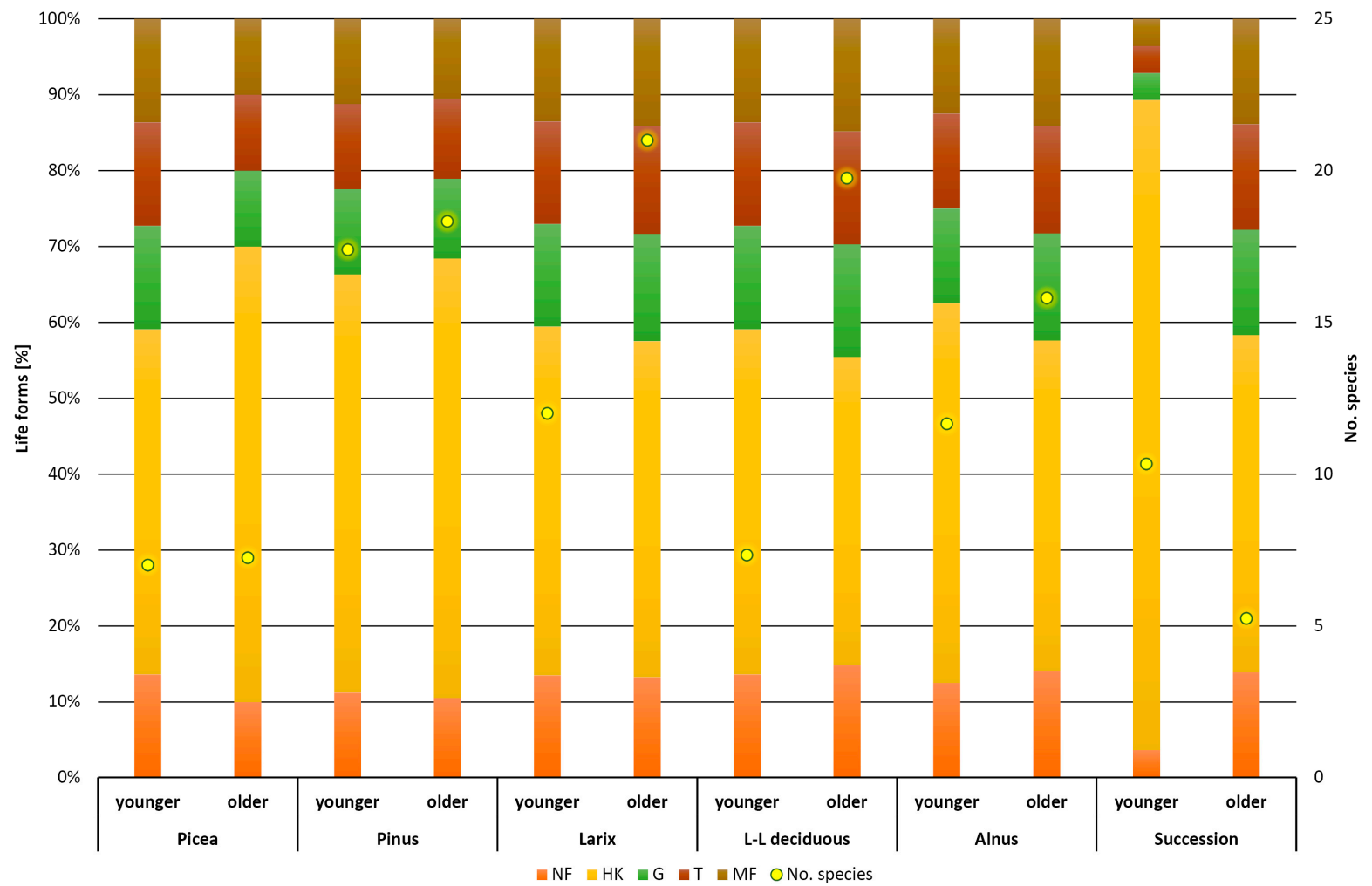

Figure 3. Raunkiær's life forms-distribution of functional groups in forest type and different ages. NF-nanophanerophyte, HF-hemicryptophyte, G-geophyte, T-therophyte, MF-macrophanerophyte. 
25

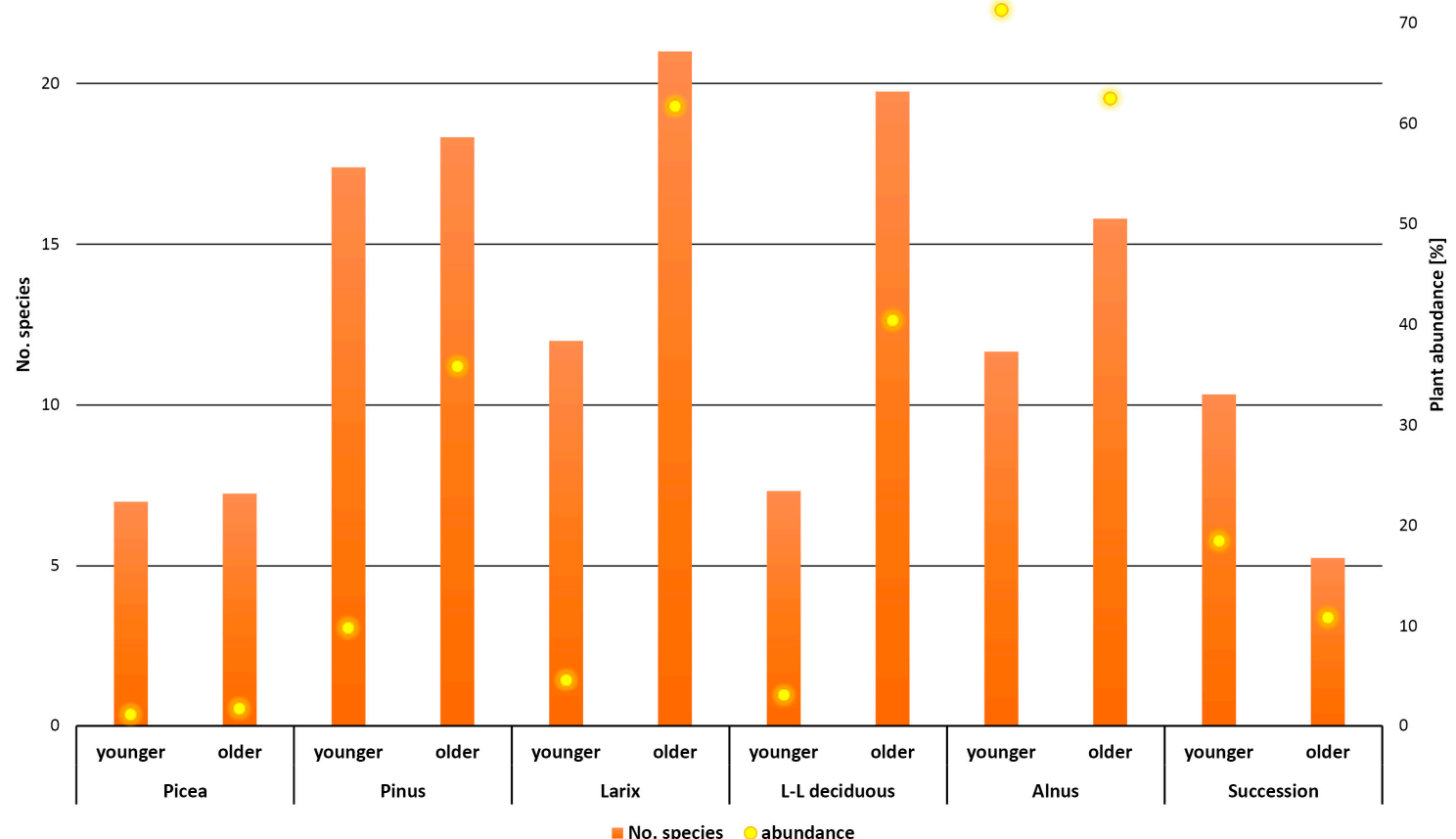

Figure 4. The number of species relative to total herb abundance (TAHL). A number of species and total plant abundance in forest type and different ages.

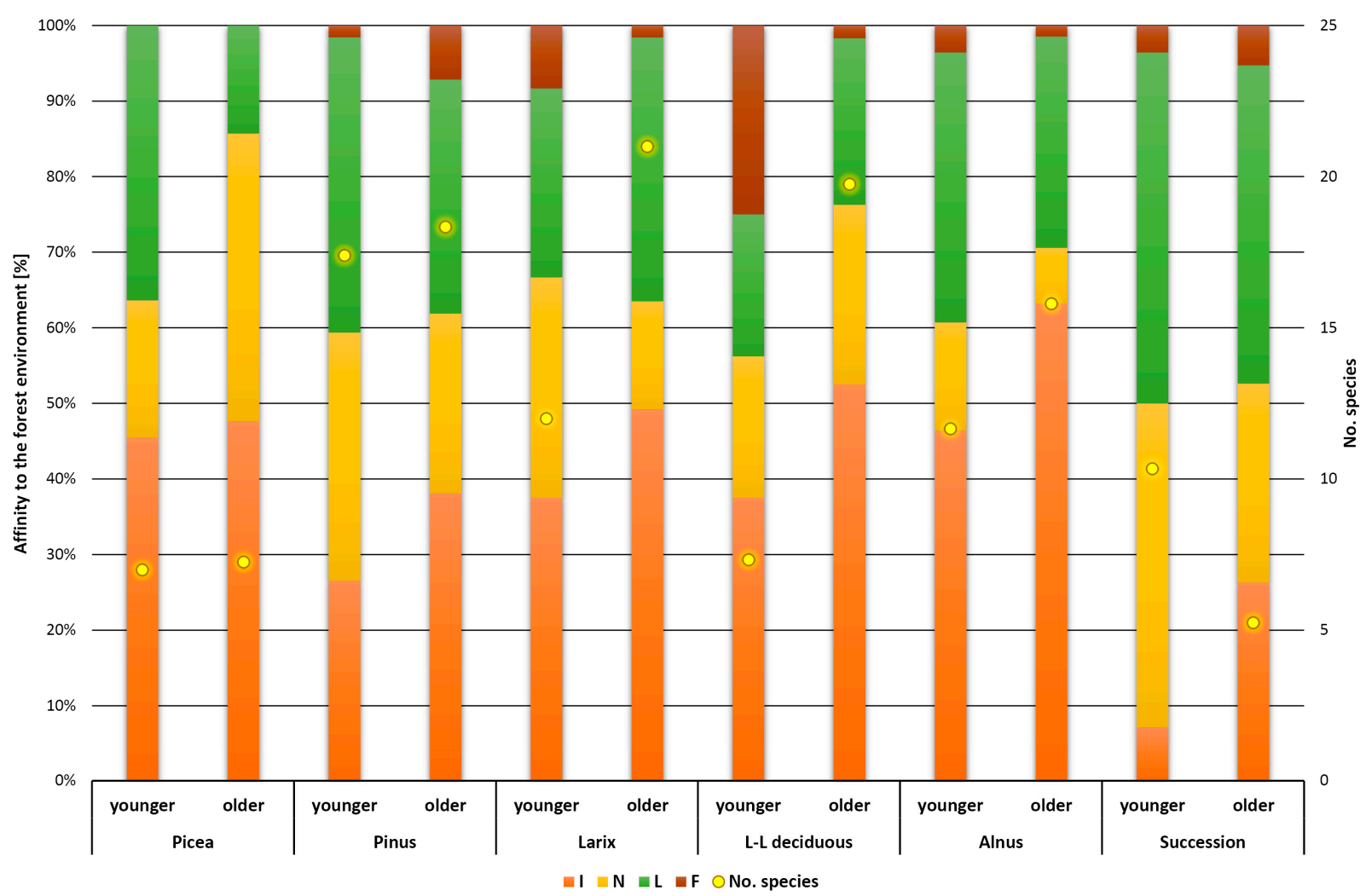

Figure 5. Affinity to the forest environment-distribution of functional groups in forest type and different ages. I-species occurring both in the forest and non-forest vegetation, $\mathrm{N}$-species without spontaneously occurring in Czech forests, L-relatively a forest species, F-forest species. 
Older Pinus stands had the highest measured total carbon levels, which were demonstrably different from those of younger Larix stands (Table 1). Total nitrogen levels did not differ between sites $(\mathrm{F}=2.487 ; p=0.059)$, but because these values were of borderline significance, a Tukey's post hoc test was performed to distinguish between younger Larix stands and younger long-lived deciduous stands (Table 1).

Table 1. Results of factorial ANOVA for soil properties. Letters indicate significant differences based on post hoc Tukey test.

\begin{tabular}{|c|c|c|c|c|c|c|c|}
\hline Type & Age & $\mathrm{pH}\left(\mathrm{CaCl}_{2}\right)$ & $\mathrm{TC} *[\%]$ & $\mathrm{TN} *[\%]$ & C/N [-] & $\mathbf{D} *[-]$ & Humus Thickness [cm] \\
\hline \multirow{2}{*}{ Alnus } & younger & $7.4^{\mathrm{ab}}$ & $9.27 \mathrm{abcd}$ & $0.57^{\mathrm{ac}}$ & $16^{\mathrm{ab}}$ & $0.92^{b}$ & $4.42^{\mathrm{ab}}$ \\
\hline & older & $6.1^{a b c}$ & $8.98^{a b c d}$ & $0.58^{\mathrm{ac}}$ & $16^{a b}$ & $0.48^{a b}$ & $9.55^{c}$ \\
\hline \multirow{2}{*}{ Larix } & younger & $7.1^{\mathrm{abc}}$ & $5.82^{a}$ & $0.26^{\mathrm{b}}$ & $23^{b c}$ & $0.22^{\mathrm{a}}$ & $3.19 \mathrm{ab}$ \\
\hline & older & $6.8^{a b c}$ & $10.87^{c d}$ & $0.39 \mathrm{ab}$ & $28^{c d}$ & $0.65^{a b}$ & $7.33^{a c}$ \\
\hline \multirow{2}{*}{ L-L Deciduous } & younger & $7.4^{\mathrm{ab}}$ & $10.36^{b c d}$ & $0.75^{\mathrm{c}}$ & $13^{a}$ & $0.34^{\mathrm{ab}}$ & $10.00^{c}$ \\
\hline & older & $7.3^{a b}$ & $8.36^{a b c}$ & $0.56^{\mathrm{ac}}$ & $14^{\mathrm{a}}$ & $0.23^{a}$ & $7.07^{\mathrm{ac}}$ \\
\hline \multirow{2}{*}{ Picea } & younger & $7.5^{b}$ & $6.40^{\mathrm{abc}}$ & $0.41^{a b}$ & $15^{a b}$ & $0.06^{\mathrm{a}}$ & $3.81^{a b}$ \\
\hline & older & $5.7^{c}$ & $6.16^{a b}$ & $0.40^{\mathrm{ab}}$ & $15^{a b}$ & $0.36^{a b}$ & $3.59^{a b}$ \\
\hline \multirow{2}{*}{ Pinus } & younger & $7.0^{\mathrm{abc}}$ & $6.70^{\mathrm{abc}}$ & $0.35^{\mathrm{ab}}$ & $19^{a b}$ & $0.17^{a}$ & $2.95^{a b}$ \\
\hline & older & $5.9^{\mathrm{ac}}$ & $13.29^{d}$ & $0.39^{a b}$ & $35^{d}$ & $0.24^{\mathrm{a}}$ & $5.46^{a b c}$ \\
\hline \multirow{2}{*}{ Succession } & younger & $5.6^{c}$ & $6.24^{a b}$ & $0.48^{a b}$ & $12^{a}$ & $0.54^{\mathrm{ab}}$ & $2.33^{b}$ \\
\hline & older & $7.4^{\mathrm{ab}}$ & $6.32^{a b}$ & $0.41^{a b}$ & $15^{a b}$ & $0.55^{a b}$ & $3.92^{a b}$ \\
\hline F & $(5 ; 24)$ & 10.486 & 7.59 & 2.487 & 6.691 & 2.766 & 5.315 \\
\hline$p$ & 0.05 & $<0.001$ & $<0.001$ & 0.059 & $<0.001$ & 0.041 & 0.002 \\
\hline
\end{tabular}

The lowest measured A horizon depth was recorded for the younger successional stages. In contrast, the deepest horizon was recorded in older Alnus stands and on longlived deciduous stands (Table 1). The highest $\mathrm{C} / \mathrm{N}$ ratio (Figure 6, Table 1) was recorded in Pinus stands. These stands differed significantly from long-lived deciduous, Picea, Alnus, and successional stands $(\mathrm{F}=6,691 ; p<0.001)$. There was no joint effect of forest type and age $(\mathrm{F}=1.724 ; p=0.168)$. Thus, stand type was a significant factor influencing the $\mathrm{C} / \mathrm{N}$ ratio. Using forward selection analysis with Bonferroni correction, we identified the depth of the $\mathrm{C} / \mathrm{N}$ ratio $(p=0.036)$ and A horizon $(p=0.072)$ as the best fit to the distribution of our data. There was no further explained variability for tree canopy cover $(p=0.234)$ or $\mathrm{pH}(p=0.712)$. When we tested the variables without Bonferroni or other correction, $\mathrm{C} / \mathrm{N}(p=0.006)$, A horizon depth $(p=0.012)$, and canopy $(p=0.039)$ emerged as significant factors. We, therefore, chose the variable $\mathrm{C} / \mathrm{N}$ as a representative environmental gradient along which plant species were distributed in terms of their habitat requirements; this relationship can be visually represented using Van Dobben circles (Figure 7). Species such as Aegopodium podagraria, Ranunculus repens, Calamagrostis epigejos, Geum urbanum, Festuca ovina, Dactylis glomerata, Rosa sp., and Symphytum officinale have affinity for lower values of C/N. Affected species include Carduus acanthoides, Artemisia vulgaris, Fagus sylvatica, Monotropa hypopitys, Salvia pratensis, Betula pendula, Agrostis stolonifera, Lathyrus pratensis, Leontodon hispidus, Crataegus sp., Lysimachia nummularia, Arctium lappa, Festuca rubra, Scrophularia nodosa, Trifolium dubium, Daucus carota, Luzula luzuloides, Festuca arundinacea, and Solidago canadensis. 

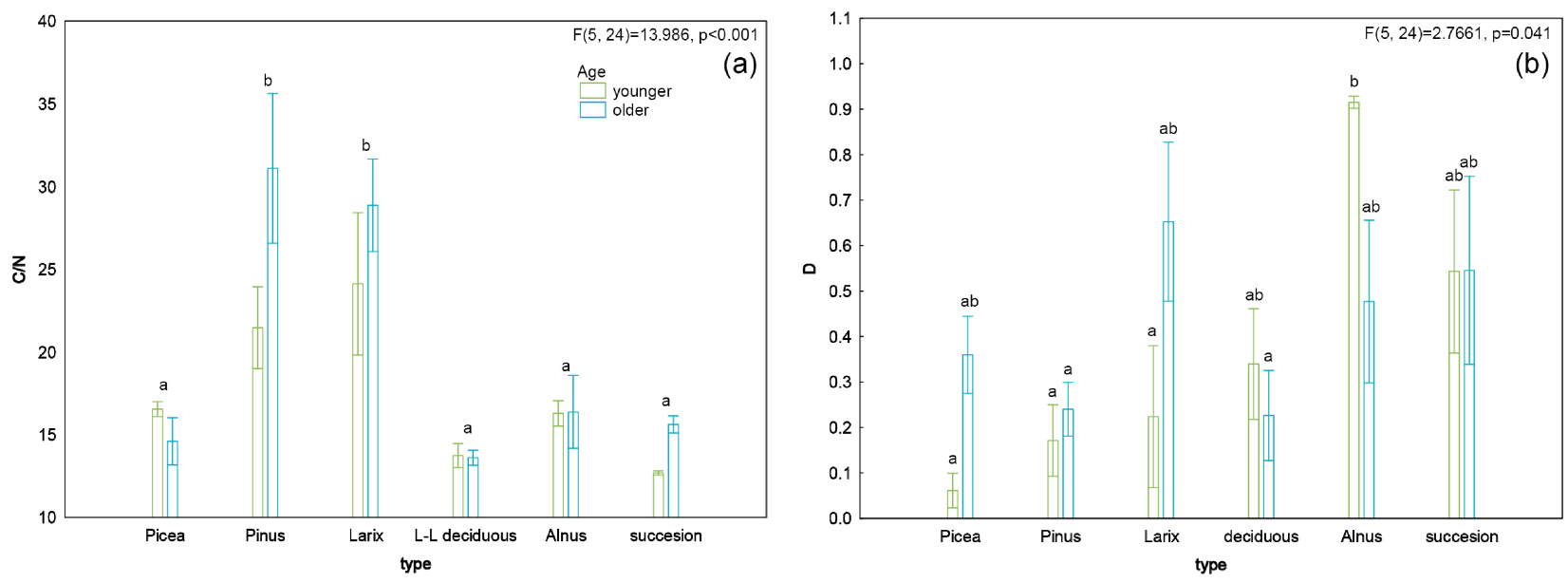

Figure 6. Results of factorial ANOVA. (a) C/N ratio, (b) D-Simpson's diversity index. Error bars indicate standard errors, and bar height is the mean value. Categories on the $\mathrm{X}$-axis show stand type in two age categories (younger-green, older-blue). The letters indicate significant differences based on the post hoc Tukey test, assuming $p<0.05$.

Plant diversity as expressed by the Simpson's index (Figure 6b) varied among stand types $(\mathrm{F}=2.8, p=0.04)$. The highest values were measured in younger stands of Alnus and the lowest in younger stands of Picea. Interesting results were obtained in successional stands of both age categories and in older stands of Larix and Alnus. The Larix stands in the younger stages were species-poor, but with increasing age many species entered the understorey, and diversity increased significantly. The CCA analysis (Figure 8a) shows the different characteristics of the studied forest stands over time. $\mathrm{C} / \mathrm{N}$, A horizon depth, and tree canopy were used as explanatory variables. These factors were selected as best explained by the forward selection function (above). The projections showed that younger stands of Alnus and Larix typically have a dense canopy, but canopy cover decreases with increasing age. The change over time is most pronounced in stands of Alnus, Larix, and long-lived deciduous trees. Over a period of about 20 years, the tree canopy becomes looser, but at the same time, due to well-distributed litter, a good humus is formed, represented by the horizon A. Succession stands have a lower tree canopy richness at younger stages due to natural, gradual, and spontaneous colonization by different tree species, dominated by Salix or Betula, and canopy cover increases with stand age. The least striking changes, in terms of crown involvement and A horizon development, occurred in Picea stands, which did not differ much from each other. Picea and Pinus stands also did not differ much in terms of the parameters observed at younger stages. The A horizon deepened as the tree canopy became more open.

The CCA analysis (Figure 8b) shows the best fitting species of the monitored stands. For Alnus (older phase) it was Rosa sp., Festuca ovina agg., or Pastinaca sativa and species of the genera Rubus and Ribes. In the older phase, the communities of alder stands, larches, and longleaf deciduous trees were mainly composed of species that occur in either forest or non-forest environments, but shrubs or trees were also found in the herbaceous layer (Prunus, Alnus, Rubus, and Ribes). The best fitting species of younger long-lived deciduous trees were Hypericum perforatum (non-forest species), Ligustrum vulgare, and Tanacetum vulgare. Festuca gigantea is one of the forest species. Non-forest species such as Crepis biennis, Tussilago farfara, Medicago lupulina, and Poa compressa were found in the herbaceous layer. The phase was characterized by a greater representation of the tree layer. A species typical of forest edges and clearings, Epipactis helleborine, was also recorded. However, typical non-forest species such as Melilotus albus or Trifolium pratense were also found in the stands. In one case, the invasive species Impatiens parviflora was found. Older long-aged broadleaves resemble older stands of Alnus in terms of their observed characteristics. 


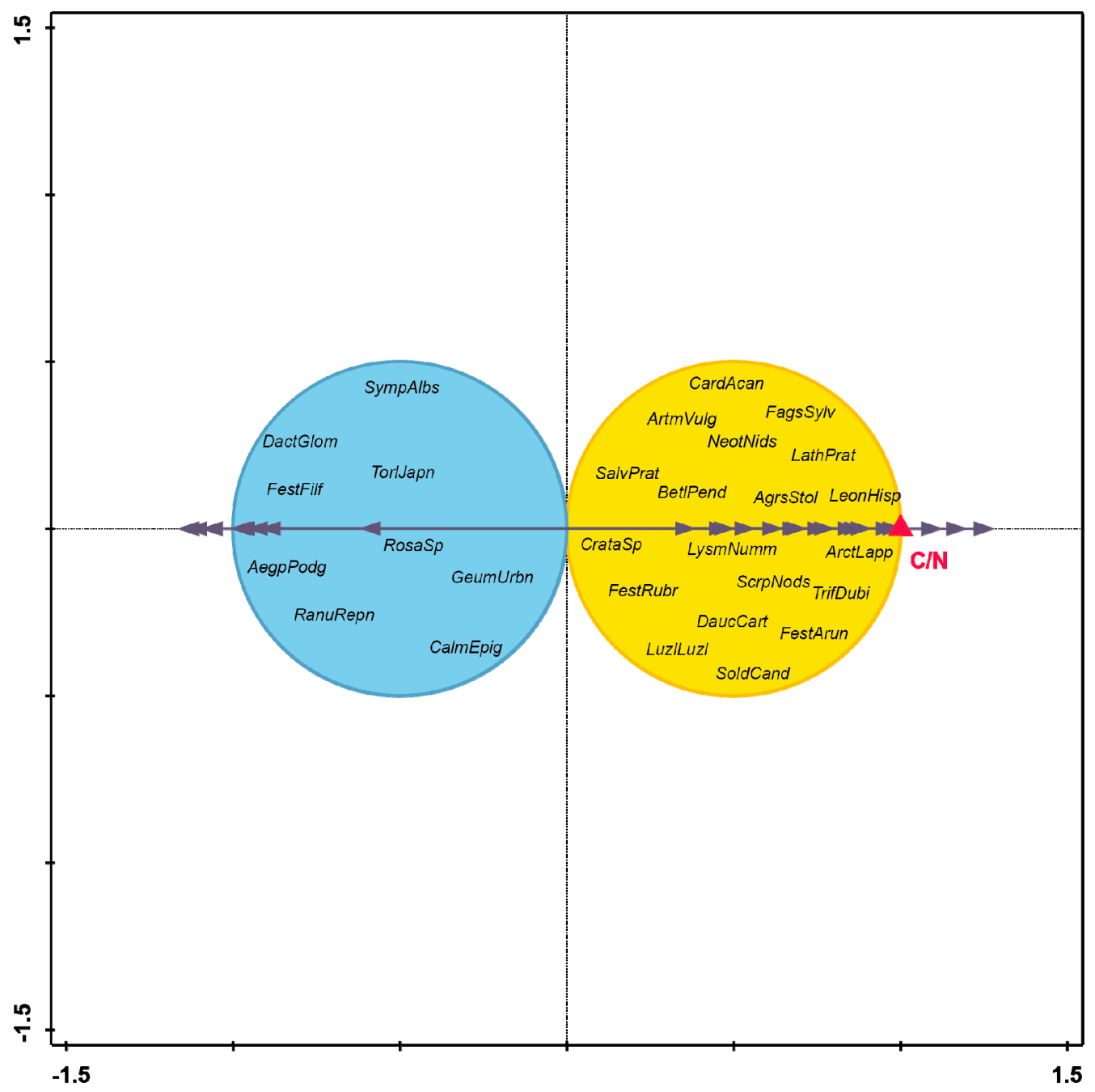

Figure 7. Van Dobben circles on the bases of CCA, the blue circle shows species negative responses, and the yellow ring shows the positive reactions of species on the $\mathrm{C} / \mathrm{N}$ ratio (red triangle). Aegopodium podagraria-AegpPodg; Agrostis stolonifera-AgrsStol; Arctium lappa-ArctLapp; Artemisia vulgarisArtmVulg; Betula pendula_BetlPend; Carduus acanthoides_CardAcan; Calamagrostis epigejos-CalmEpig; Crataegus sp. -CrataSp; Dactilis glomerata-DactGlom; Daucus carota-DaucCart; Fagus sylvaticaFagsSylv; Festuca arundinacea-FestArun; Festuca ovina-Festovin; Festuca rubra-FestRubr; Geum urbanum-GeumUrbn; Lathyrus pratensis-LathPrat; Leontodon hispidus_LeonHisp; Luzula luzuloidesLuzlLuzl; Lysimachia nummularia-LysmNumn; Neottia nidus-avis-NeotNids; Ranunculus repensRanuRepn; Rosa sp.—RosaSp; Salvia —SalvPrat; Scrophularia nodosa-ScrpNods; Solidago canadensisSoldCand; Symphoricarpos albus_SympAlbs; Torilis japonica-TorlJapn; Trifolium dubium-TrifDubi. 

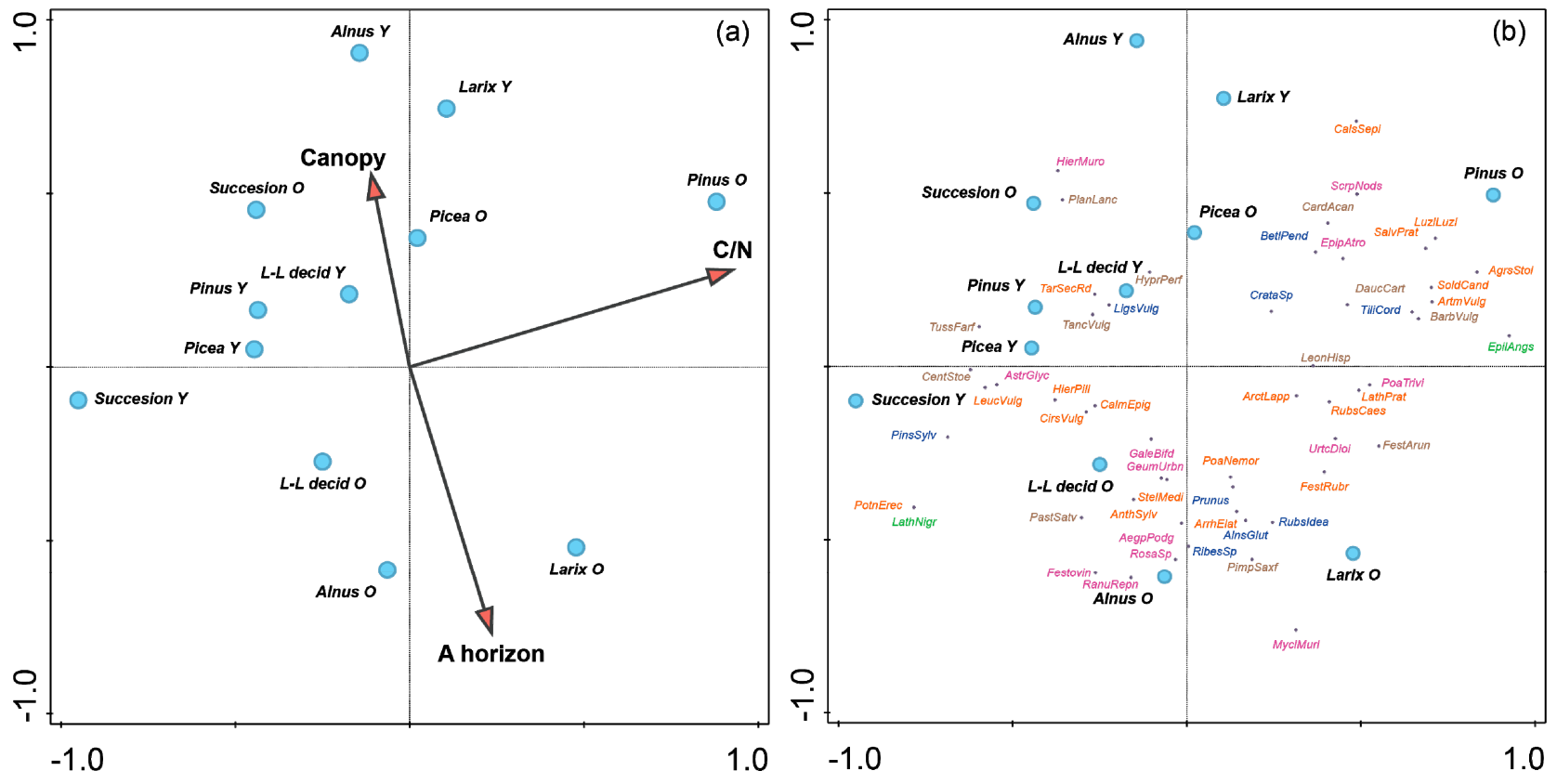

Figure 8. CCA with supplementary variables (forest type and age). Total explanatory variables account for $13.25 \%$. The first ordination axis included $37.99 \%$ of the data variability, and the second included $35.25 \%$. Blue points indicate forest types differentiated by age (Y-younger, $\mathrm{O}-\mathrm{older}$ ), the abbreviation L-L decid indicates long-lived deciduous trees. (a) CCA with supplementary variables (forest type) with environmental variables (humus, canopy, C/N ratio); (b) CCA with supplementary variables (forest type) with species context. The 55 most fitting species are listed. Species differentiated according to affinity to forest environment (brown-non-forest; green-forest; red-rather non-forest; purple-inert; blue tree/shrub). Artemisia vulgaris-ArtmVulg; Astragalus glycyphyllos-AstrGlyc; Barbarea vulgaris-BarbVulg; Betula pendula-BetlPend; Calamagrostis epigejosCalmEpig; Calystegia sepium-CalsSepi; Carduus acanthoides-CardAcan; Centaurea stoebe-CentStoe; Cirsium vulgare-CirsVulg; Crataegus sp. —CrataSp; Daucus carota-DaucCart; Epilobium angustifoliumEpilAngs; Epipactis atrorubens_EpipAtro; Festuca arundinacea_FestArun; Festuca ovina_Festovin; Festuca rubra-FestRubr; Galeopsis bifida-GaleBifd; Geum urbanum-GeumUrbn; Hieracium murorumHierMuro; Hieracium pillosela — HierPill; Hypericum perforatum-HyprPerf; Lathyrus niger-LathNigr; Lathyrus pratensis_LathPrat; Leontodon hispidus_LeonHisp; Leucanthemum vulgare-LeucVulg; Ligustrum vulgare_LigsVulg; Luzula luzuloides_LuzlLuzl; Mycelis muralis_MyclMurl; Pastinaca sativaPastSatv; Pimpinella saxifraga_PimpSaxf; Pinus sylvestris—PinsSylv; Plantago lanceolata_PlanLanc; Poa nemoralis-PoaNemor; Poa trivialis_PoaTrivi; Potentilla erecta-PotnErec; Prunus_Prunus; Ranunculus repens-RanuRepn; Ribes sp.-RibesSp; Rosa sp.-RosaSp; Rubus caesius-RubsCaes; Rubus ideausRubsIdea; Salvia pratensis-SalvPrat; Scrophularia nodosa-ScrpNods; Solidago canadensis-SoldCand; Stellaria media-StelMedi; Tanacetum vulgare-TancVulg; Taraxacum sec. Ruderalia-TarSecRd; Tilia cordata-TiliCord; Tussilago farfara-TussFarf; Urtica dioica-UrtcDioi.

The species composition of the plant community resulting from spontaneous succession was characterized by a fairly balanced representation of forest and non-forest species, especially in the younger phase. In this phase, Calamagrostis epigejos or Tussilago farfara was still the dominant species. In older stands, non-forest species were declining due to the greater canopy cover. The endangered taxon Pyrola minor (near-threatened category, IUCN) was recorded in these stands. Younger Larix stands were characterized by a low abundance of species in the herbaceous floor (Figure 4). The observed species involved only a few individuals. Non-forest species were mainly represented by Poa compressa, Crepis biennis, and Carduus acanthoides. Of the forest species, Milium effusum was recorded. Older phases of Larix stands were among the most species-rich stand types. The reason for this was probably the change in soil conditions, loosening up of the canopy, and subsequently, the 
occurrence of heliophytes. The plant communities here were well developed. Non-forest species of the genus Festuca or Achillea millefolium and Pimpinella saxifraga and a relatively large number of seedlings of other woody plants were well established in these stands.

The younger Pinus stands lacked mature herbaceous vegetation. The understorey consisted mainly of non-forest or rarely occurring species in forest stands. These were probably species that were retreating from the previous growth phase. The number of species in the stands did not change significantly, but the herbaceous understorey increased in abundance. There were still no forest species, but species that occur mainly in non-forest habitats such as Artemisia vulgaris and Daucus carota were found. The Picea stands in both phases did not have a developed herbaceous understorey. Species occurring in the younger stands of the previous phase tended to disappear. Once the forest cover was established, there was not enough light penetrating the lower levels, and the soil conditions were unfavourable for plant growth.

\section{Discussion}

In this study, we investigated differences in forest reclamation and succession in terms of biodiversity, plant functional groups, and selected soil properties. In the case of forest reclamation, seedlings were placed directly into the backfill. Borůvka et al. [43] reported that topsoil application improved initial substrate quality, but this approach is only applicable to small areas. Taking into account the cost of planting and replanting dead seedlings, and the time required, this is a very costly restoration relative to the alternative of spontaneous succession $[20,21,44,45]$.

Community structure is influenced by many biotic and abiotic factors $[24,32,33]$. The initiation of pile processing and the type of dominant woody plant are the critical factors in the ecosystem that determine the direction of community development [46]. Forest type determines the composition of the herbaceous understory. Each stand type develops a specific plant community, so a forest should be planned as a mosaic of different species $[29,30]$. Deciduous tree species influence soil biological properties more than conifers [34], as soils in deciduous forests are more fertile than in coniferous forests [47]. For example, Pinus stands have a slowly decomposing understory compared to that under deciduous trees, again slowing down pedogenesis [48]. Larix stands performed relatively well in this experiment, but the ambiguity of views on the natural distribution of this species should be taken into account $[40,49]$. Non-native species can sometimes increase plant diversity and habitat heterogeneity, including soil characteristics, but this carries risks of potential invasion [50], especially for Alnus stands. These have a higher proportion of herbaceous vegetation and higher biomass production due to faster nutrient cycling, including better nitrogen availability, which increases the risk of invasiveness [50-54]. Since Alnus stands start to decline much earlier than other monitored stands, it would be advisable to have further plantings allocated in the forest management plan or the management plan, if the area is protected. In terms of pedogenesis and speed of preparation for subsequent use, Alnus is a suitable solution, including for landscaping. Vacek et al. [54,55] stated that Alnus-dominated forestry reclamations were quite popular; however, in the case of the Sokolov spoil heaps, such stands were definitely underrepresented.

Picea stands did not reach favourable ecological parameters. Picea on spoil heaps generally does not perform well $[55,56]$ because of edaphic and geographic reasons. Picea is not a natural dominator of the vegetation in this area [26]. Edaphic factors and high tree abundance also play important roles in Pinus stands. Once the forest canopy becomes denser, not enough light penetrates to the lower levels, and soil conditions are less favourable for plant growth [18]. Low abundance in the younger stages does not necessarily imply low abundance in the following years, as shown by the results of measurements in long-lived deciduous, Pinus, and Larix stands, where the age of the site may influence growth $[56,57]$.

In this study, the most important factors determining the plant community type were the soil $\mathrm{C} / \mathrm{N}$ ratio and the humus horizon thickness, which correspond with the soil biological activity [24]. According to previous studies, in the early stages of the 
spoil heap development, soils have a low content of readily available organic matter and nitrogen $[57,58]$. Composition of tree species is a very important variable that determines the $\mathrm{C} / \mathrm{N}$ ratio of soils [58,59]. Picea stands had a surprisingly low $\mathrm{C} / \mathrm{N}$ ratio, which is in contrast to other studies $[59,60]$. This fact is explained by the sampling scheme below the organic horizon with trace of fermentation processes, where there is a large amount of clay and consequently less organic matter. According to Frouz et al. [33], time has a great influence on the community. Over time, forest species should start to appear in the understorey, but the problem is with the quality of the diaspore source. The area is mainly characterized by species-poor, unnatural spruce stands, but even these types of habitats can contribute to carbon sequestration, albeit with a different distribution within the ecosystem compared to natural forests $[60,61]$. There were no significant differences in species differentiation by life form, which is not consistent with Piekarska-Stachowiak et al. [61,62]. The different results may be explained by different geographical conditions (temperature, altitude), as these factors are often the main drivers of the community $[62,63]$. The slower development of the plant community in Picea stands compared to others is shown by the fact that no species with a CS strategy was found at any age stage [21].

The herbaceous vegetation in the different stands differed significantly. The dominant tree species strongly influenced pedogenesis and the herbaceous layer [18,29-31]. Forest reclamations are often formed as monoculture strips, and on longer time scales, reclaimed forests do not lag behind the nearby commercial forests [63,64]. However, spoil heap reclamation should be planned as a diverse mosaic of habitats with both technical and successional components $[27,28,64,65]$. Deciduous trees from spontaneous succession or reclamation appear to be best from a landscape stability perspective $[65,66]$. Vegetation, soil, and soil biota are components that are tightly intertwined and interdependent [33] and depend heavily on the characteristics of the tree canopy [34].

\section{Conclusions}

This study identified $\mathrm{C} / \mathrm{N}$ ratio, A horizon depth, and tree cover as important factors shaping the herbaceous vegetation of the spoil heaps. Plant communities change over time, but the relatedness of functional groups with vegetation type and age could not be traced in the vegetation of the spoil heaps. Therefore, we do not consider these functional groups to be determinative for this type habitats. Herbaceous vegetation does not change significantly in Picea stands, where the abundance of the herbaceous floor is low even at older ages. For sustainable forestry reclamation, we propose that it should be planned as a deciduous or mixed forest. We recommend that the mix should include mainly alder, long-standing broadleaves and, if conditions are right, Larix. The combination of these species should also have an impact on plant diversity and soil characteristics. A large number of sites are still technically reclaimed, although spontaneous succession is a very suitable alternative, as is managed succession, as other studies have shown. We, therefore, recommend combining spontaneous succession with technical reclamation if biotic and abiotic factors of habitats favour this solution.

Author Contributions: Conceptualization, P.V., A.W. and O.M.; methodology, P.V.; software, P.V.; formal analysis, P.V., H.H., K.K., O.V. and M.B.; investigation, P.V., A.W., M.V. and O.V.; writingoriginal draft preparation, P.V., M.S. and M.V.; writing—review and editing, P.V., A.W., M.S., M.V. and O.M.; visualization, P.V. and M.S.; supervision, O.M. All authors have read and agreed to the published version of the manuscript.

Funding: This research was supported by the Ministry of Agriculture of the Czech Republic (project no. QK1710241, Optimization of management of forest restoration on sites affected by surface mining).

Institutional Review Board Statement: Not applicable.

Informed Consent Statement: Not applicable.

Data Availability Statement: Not applicable.

Conflicts of Interest: The authors declare no conflict of interest. 


\section{References}

1. Tropek, R.; Kadlec, T.; Hejda, M.; Kocarek, P.; Skuhrovec, J.; Malenovsky, I.; Vodka, S.; Spitzer, L.; Banar, P.; Konvicka, M. Technical reclamations are wasting the conservation potential of post-mining sites. A case study of black coal spoil dumps. Ecol. Eng. 2012, 43, 13-18. [CrossRef]

2. Hendrychová, M.; Kabrna, M. An analysis of 200-year-long changes in a landscape affected by large-scale surface coal mining: History, present and future. Appl. Geogr. 2016, 74, 151-159. [CrossRef]

3. Van Grunsven, R.H.A.; van Der Putten, W.H.; Martijn Bezemer, T.; Berendse, F.; Veenendaal, E.M. Plant-soil interactions in the expansion and native range of a poleward shifting plant species. Glob. Chang. Biol. 2010, 16, 380-385. [CrossRef]

4. Hickling, R.; Roy, D.B.; Hill, J.K.; Fox, R.; Thomas, C.D. The distributions of a wide range of taxonomic groups are expanding polewards. Glob. Chang. Biol. 2006, 12, 450-455. [CrossRef]

5. Dhar, A.; Comeau, P.G.; Naeth, M.A.; Pinno, B.D.; Vassov, R. Plant community development following reclamation of oil sands mines using four cover soil types in northern Alberta. Restor. Ecol. 2020, 28, 82-92. [CrossRef]

6. Jagodziński, A.M.; Wierzcholska, S.; Dyderski, M.K.; Horodecki, P.; Rusińska, A.; Gdula, A.K.; Kasprowicz, M. Tree species effects on bryophyte guilds on a reclaimed post-mining site. Ecol. Eng. 2018, 110, 117-127. [CrossRef]

7. Brown, S.N.; Swab, R.M. To Establish a Healthy Forest: Restoration of the Forest Herb Layer on a Reclaimed Mine Site. Am. Midl. Nat. 2021, 186, 35-50. [CrossRef]

8. Pyšek, P.; Danihelka, J.; Sádlo, J.; Chrtek, J., Jr.; Chytrý, M.; Jarošik, V.; Kaplan, Z.; Krahulec, F.; Moravcová, L.; Pergl, J.; et al. Catalogue of alien plants of the Czech Republic (2nd edition): Checklist update, taxonomic diversity and invasion patterns. Preslia 2012, 84, 155-255.

9. Pergl, J.; Sádlo, J.; Petrusek, A.; Laštuvka, Z.; Musil, J.; Perglová, I.; Šanda, R.; Šefrová, H.; Šíma, J.; Vohralík, V.; et al. Black, Grey and Watch Lists of alien species in the Czech Republic based on environmental impacts and management strategy. NeoBiota 2016, 28, 1-37. [CrossRef]

10. Ťehounková, K.; Prach, K. Spontaneous vegetation succession in gravel-sand pits: A potential for restoration. Restor. Ecol. 2008, 16, 305-312. [CrossRef]

11. Sun, D.; Müllerová, V.; Ardestani, M.M.; Frouz, J. Nitrogen fertilization and its legacy have inconsistent and often negative effect on plant growth in undeveloped post mining soils. Soil Tillage Res. 2019, 195, 104380. [CrossRef]

12. Czech, B.; Krausman, P.R.; Devers, P.K. Economic Associations among Causes of Species Endangerment in the United States. Bioscience 2000, 50, 593-601. [CrossRef]

13. Begon, M.; Harper, J.L.; Townsend, C.R. Ecology: Individuals, Populations and Communities; Vydavatelství Univerzity Palackého: Olomouc, Czech Republic, 1997; ISBN 80-7067-695-7.

14. Grime, J.P. Plant Strategies, Vegetation Processes, and Ecosystem Properties; Wiley: Hoboken, NJ, USA, 2006; ISBN 047085040X.

15. Hejcman, M.; Strnad, L.; Hejcmanová, P.; Pavlů, V. Response of plant species composition, biomass production and biomass chemical properties to high N, P and K application rates in Dactylis glomerata and Festuca arundinacea dominated grassland. Grass Forage Sci. 2012, 67, 488-506. [CrossRef]

16. Miletić, Z.; Knežević, M.; Stajić, S.; Košanin, O.; Đorđević, I. Effect of European Black Alder Monocultures on The Characteristics of Reclaimed Mine Soil. Int. J. Environ. Res. 2012, 6, 703-710.

17. Woś, B.; Smoliński, A.; Likus-Cieślik, J.; Pietrzykowski, M. The impact of alder litter on chemistry of Technosols developed from lignite combustion waste and natural sandy substrate: A laboratory experiment. Int. J. Phytoremediation 2020, 23, 415-425. [CrossRef] [PubMed]

18. Mudrák, O.; Frouz, J.; Velichová, V. Understory vegetation in reclaimed and unreclaimed post-mining forest stands. Ecol. Eng. 2010, 36, 783-790. [CrossRef]

19. Elton, C.S. The Ecology of Invasions by Animals and Plants; Springer: Boston, MA, USA, 1958; ISBN 978-0-412-11430-4.

20. Šebelíková, L.; Csicsek, G.; Kirmer, A.; Vítovcová, K.; Ortmann-Ajkai, A.; Prach, K.; Řehounková, K. Spontaneous revegetation versus forestry reclamation-Vegetation development in coal mining spoil heaps across Central Europe. L. Degrad. Dev. 2019, 30, 348-356. [CrossRef]

21. Hodačová, D.; Prach, K. Spoil heaps from brown coal mining: Technical reclamation versus spontaneous revegetation. Restor. Ecol. 2003, 11, 385-391. [CrossRef]

22. Frouz, J.; Mudrák, O.; Reitschmiedová, E.; Walmsley, A.; Vachová, P.; Šimáčková, H.; Albrechtová, J.; Moradi, J.; Kučera, J. Rough wave-like heaped overburden promotes establishment of woody vegetation while leveling promotes grasses during unassisted post mining site development. J. Environ. Manag. 2018, 205, 50-58. [CrossRef]

23. Veselá, H.; Mudrák, O.; Frouz, J. The role of dead standing biomass of Calamagrostis epigejos in nutrient turnover during spontaneous succession. Sci. Total Environ. 2018, 644, 717-724. [CrossRef]

24. Walmsley, A.; Vachová, P.; Vach, M. Topography of Spoil Heaps and Its Role in Plant Succession and Soil Fauna Presence. Sci. Agric. Bohem. 2017, 48, 30-38. [CrossRef]

25. Vicentini, F.; Hendrychova, M.; Tajovskỳ, K.; Pižl, V.; Frouz, J. The effect of topography on long-term spontaneous development of soil and woody cover on graded and untreated overburden. Forests 2020, 11, 602. [CrossRef]

26. Neuhäuslová, Z. Map of Potential Natural Vegetation of the Czech Republic; Academia: Prague, Czech Republic, 2001.

27. Harabiš, F.; Tichanek, F.; Tropek, R. Dragonflies of freshwater pools in lignite spoil heaps: Restoration management, habitat structure and conservation value. Ecol. Eng. 2013, 55, 51-61. [CrossRef] 
28. Hendrychová, M.; Šálek, M.; Tajovský, K.; Řehoř, M. Soil Properties and Species Richness of Invertebrates on Afforested Sites after Brown Coal Mining. Restor. Ecol. 2012, 20, 561-567. [CrossRef]

29. Rawlik, M.; Kasprowicz, M.; Jagodziński, A.M.; Kaźmierowski, C.; Łukowiak, R.; Grzebisz, W. Canopy tree species determine herb layer biomass and species composition on a reclaimed mine spoil heap. Sci. Total Environ. 2018, 635, 1205-1214. [CrossRef]

30. Rawlik, M.; Kasprowicz, M.; Jagodziński, A.M. Differentiation of herb layer vascular flora in reclaimed areas depends on the species composition of forest stands. For. Ecol. Manag. 2018, 409, 541-551. [CrossRef]

31. Roubíčková, A.; Mudrák, O.; Frouz, J. Effect of earthworm on growth of late succession plant species in postmining sites under laboratory and field conditions. Biol. Fertil. Soils. 2009, 45, 769-774. [CrossRef]

32. Jačka, L.; Walmsley, A.; Kovář, M.; Frouz, J. Effects of different tree species on infiltration and preferential flow in soils developing at a clayey spoil heap. Geoderma 2021, 403, 115372. [CrossRef]

33. Frouz, J.; Prach, K.; Pižl, V.; Hanel, L.; Starý, J.; Tajovský, K.; Materna, J.; Balík, V.; Kalcik, J.; Rehounkova, K. Interactions between soil development, vegetation and soil fauna during spontaneous succession in post mining sites. Eur. J. Soil Biol. 2008, 44, 109-121. [CrossRef]

34. Józefowska, A.; Woś, B.; Pietrzykowski, M. Tree species and soil substrate effects on soil biota during early soil forming stages at afforested mine sites. Appl. Soil Ecol. 2016, 102, 70-79. [CrossRef]

35. Roman, A.; Gafta, D. Proximity to successionally advanced vegetation patches can make all the difference to plant community assembly. Plant Ecol. Divers. 2013, 6, 269-278. [CrossRef]

36. Hendrychová, M.; Svobodova, K.; Kabrna, M. Mine reclamation planning and management: Integrating natural habitats into post-mining land use. Resour. Policy 2020, 69, 101882. [CrossRef]

37. Rojík, P. New stratigraphic subdivision of the Tertiary in the Sokolov Basin in Northwestern Bohemia. J. Czech. Geol. Soc. 2004, 49, 173-185.

38. CHMI Czech Hydrometeorological Institute. Available online: https:/ / www.chmi.cz/ (accessed on 4 September 2021).

39. Kuráž, V.; Frouz, J.; Kuráž, M.; Mako, A.; Shustr, V.; Cejpek, J.; Romanov, O.V.; Abakumov, E.V. Changes in some physical properties of soils in the chronosequence of self-overgrown dumps of the Sokolov quarry-dump complex, Czechia. Eurasian Soil Sci. 2012, 45, 266-272. [CrossRef]

40. Chytrý, M.; Danihelka, J.; Kaplan, Z.; Wild, J.; Holubová, D.; Novotný, P.; Řezníčková, M.; Rohn, M.; Dřevojan, P.; Grulich, V.; et al. Pladias Database of the Czech Flora and Vegetation Pladias-databáze české flóry a vegetace. Pladias. Database Czech Flora Veg. 2021, 93, 1-87. [CrossRef]

41. Blanchet, F.G.; Legendre, P.; Borcard, D. Forward sellection of explanatory variables. Ecology 2008, 89, 2623-2632. [CrossRef]

42. Šmilauer, P.; Lepš, J. Multivariate Analysis of Ecological Data using Canoco 5; Cambridge University Press: Cambridge, UK, 2014.

43. Borůvka, L.; Kozák, J.; Mühlhanselová, M.; Donátová, H.; Nikodem, A.; Němeček, K.; Drábek, O. Effect of covering with natural topsoil as a reclamation measure on brown-coal mining dumpsites. J. Geochemical Explor. 2012, 113, 118-123. [CrossRef]

44. Mishra, S.K.; Hitzhusen, F.J.; Sohngen, B.L.; Guldmann, J.M. Costs of abandoned coal mine reclamation and associated recreation benefits in Ohio. J. Environ. Manag. 2012, 100, 52-58. [CrossRef]

45. Plumlee, M.H.; Stanford, B.D.; Debroux, J.-F.; Hopkins, D.C.; Snyder, S.A. Costs of Advanced Treatment in Water Reclamation. Ozone Sci. Eng. 2014, 36, 485-495. [CrossRef]

46. Walmsley, A.; Vachová, P.; Hlava, J. Tree species identity governs the soil macrofauna community composition and soil development at reclaimed post-mining sites on calcium-rich clays. Eur. J. For. Res. 2019, 138, 753-761. [CrossRef]

47. Rahmonov, O.; Krzysztofik, R.; Środek, D.; Smolarek-Lach, J. Vegetation- and Environmental Changes on Non-Reclaimed Spoil Heaps in Southern Poland. Biology 2020, 9, 164. [CrossRef]

48. Horodecki, P.; Jagodziński, A.M. Tree species effects on litter decomposition in pure stands on afforested post-mining sites. For. Ecol. Manag. 2017, 406, 1-11. [CrossRef]

49. Wagner, S.; Litt, T.; Sánchez-Goñi, M.F.; Petit, R.J. History of Larix decidua Mill. (European larch) since 130 ka. Quat. Sci. Rev. 2015, 124, 224-247. [CrossRef]

50. Zhang, H.; Chu, L.M. Plant Community Structure, Soil Properties and Microbial Characteristics in Revegetated Quarries. Ecol. Eng. 2011, 37, 1104-1111. [CrossRef]

51. Burke, M.J.W.; Grime, J.P. An Experimental Study of Plant Community Invasibility. Ecology 1996, 77, 776-790. [CrossRef]

52. Chytrý, M.; Pyšek, P. Kam se šíři zavlečené rostliny? 2. Invadovanost a invazibilita rostlinných společenstev. Živa 2009, 2, 60-63. (In Czech)

53. Hobbs, R.J.; Humphries, S.E. An Integrated Approach to the Ecology and Management of Plant Invasions. Conserv. Biol. 1995, 9, 761-770. [CrossRef]

54. Lonsdale, W.M. Global Patterns of Plant Invasions And the Concept Of Invasibility. Ecology 1999, 80, 1522-1536. [CrossRef]

55. Vacek, Z.; Cukor, J.; Vacek, S.; Podrázský, V.; Linda, R.; Kovařík, J. Forest biodiversity and production potential of post-mining landscape: Opting for afforestation or leaving it to spontaneous development? Cent. Eur. For. J. 2018, 64, 116-126. [CrossRef]

56. Zhang, W.Q.; Fleurial, K.; Sherr, I.; Vassov, R.; Zwiazek, J.J. Growth and physiological responses of tree seedlings to oil sands non-segregated tailings. Environ. Pollut. 2020, 259, 113945. [CrossRef]

57. Prach, K.; Řehounková, K.; Lencová, K.; Jírová, A.; Konvalinková, P.; Mudrák, O.; Študent, V.; Vaněček, Z.; Tichý, L.; Petřík, P.; et al. Vegetation succession in restoration of disturbed sites in Central Europe: The direction of succession and species richness across 19 seres. Appl. Veg. Sci. 2014, 17, 193-200. [CrossRef] 
58. Šourková, M.; Frouz, J.; Šantrůčková, H. Accumulation of carbon, nitrogen and phosphorus during soil formation on alder spoil heaps after brown-coal mining, near Sokolov (Czech Republic). Geoderma 2005, 124, 203-214. [CrossRef]

59. Cools, N.; Vesterdal, L.; De Vos, B.; Vanguelova, E.; Hansen, K. Tree species is the major factor explaining C:N ratios in European forest soils. For. Ecol. Manag. 2014, 311, 3-16. [CrossRef]

60. Frouz, J.; Livečková, M.; Albrechtová, J.; Chroňáková, A.; Cajthaml, T.; Pižl, V.; Háněl, L.; Starý, J.; Baldrian, P.; Lhotáková, Z.; et al. Is the effect of trees on soil properties mediated by soil fauna? A case study from post-mining sites. For. Ecol. Manag. 2013, 309, 87-95. [CrossRef]

61. Lorenz, M.; Thiele-Bruhn, S. Tree species affect soil organic matter stocks and stoichiometry in interaction with soil microbiota. Geoderma 2019, 353, 35-46. [CrossRef]

62. Piekarska-Stachowiak, A.; Szary, M.; Ziemer, B.; Besenyei, L.; Woźniak, G. An application of the plant functional group concept to restoration practice on coal mine spoil heaps. Ecol. Res. 2014, 29, 843-853. [CrossRef]

63. Vítovcová, K.; Tichý, L.; Řehounková, K.; Prach, K. Which landscape and abiotic site factors influence vegetation succession across seres at a country scale? J. Veg. Sci. 2020, 32, 12950. [CrossRef]

64. Bandyopadhyay, S.; Novo, L.A.B.; Pietrzykowski, M.; Maiti, S.K. Assessment of Forest Ecosystem Development in Coal Mine Degraded Land by Using Integrated Mine Soil Quality Index (IMSQI): The Evidence from India. Forest 2020, 11, 1310. [CrossRef]

65. Kabrna, M.; Hendrychová, M.; Prach, K. Establishment of target and invasive plant species on a reclaimed coal mining dump in relation to their occurrence in the surroundings. Int. J. Min. Reclam. Environ. 2014, 28, 242-249. [CrossRef]

66. Vach, M.; Vachová, P.; Walmsley, A.; Berka, M.; Albert, J.; Cienciala, E.; Braun Kohlová, M.; Máca, V.; Melichar, J. Stochastic evaluation of restoration procedures on post-mining land areas using a game theory approach. Land Degrad. Dev. 2021. [CrossRef] 